\title{
ON THE NATURE OF THE PROTEOLYTIC SUBSTANCES IN THE BLOOD.*
}

\author{
GE ORG E F. DICK. \\ (From the Pathological Laboratory of the University of Chicago.)
}

The extensive investigation of the phenomenon of anaphylaxis has brought out the importance of parenteral protein digestion in relation to both anaphylaxis and other processes of immunity.

Vaughan, in I9o6, advanced the idea that anaphylactic shock is caused by an intoxication with protein-split products, and that the condition of hypersusceptibility is due to an increase in the protein-splitting power of the blood. Since the work of Vaughan a mass of evidence in support of this view has developed. The toxicity of protein-split products has been shown by Vaughan and Wheeler, ${ }^{2}$ and Biedl and Kraus. ${ }^{3}$ The production of protein-split products by the action of the serum of hypersensitive animals on the sensitizing antigen has been demonstrated by Pfeiffer and Mita, ${ }^{4}$ and Rosenow. ${ }^{5}$ Recently Friedberger and his associates, ${ }^{6}$ Neufeld and Dold, ${ }^{7}$ and Rosenow, ${ }^{8}$ have demonstrated the production of substances of the nature of protein-split products by the action of immune serum on bacterial antigen. Vaughan, Cummings, and Wright' have produced continuous fever by repeated injections of small quantities of protein substances such as egg white. The parenteral digestion of bacterial proteins assumes therefore an important role in the production of the intoxications associated particularly with those organisms producing the so-called endotoxins.

It is obviously desirable to see whether the proteolytic ferments of the blood resemble the immune bodies. In order to study the specificity of these ferments, Abderhalden and Pincussohn ${ }^{\mathrm{ro}}$ injected gelatin into $\operatorname{dog}_{5}$, and found that the ferments which subsequently developed split not only gelatin but also peptones from silk. With Immisch, ${ }^{\text {xI }}$ Abderhalden found that, in a similar way, ferments following injections of silk peptone split peptones from silk and edestin. With Israel ${ }^{12}$ he obtained a similar result with edestin; that is, the ferments acted upon peptones from various sources. Abderhalden and Sleeswyk ${ }^{13}$ found that ferments, developing after casein injections, acted on peptones from various sources. The conclusion drawn is that the ferments developing after these injections of proteins were not specific.

Fleischmann ${ }^{14}$ was able to obtain a precipitin for heterologous proteins by injecting into animals, split products of proteins. According to Fleischmann, and also

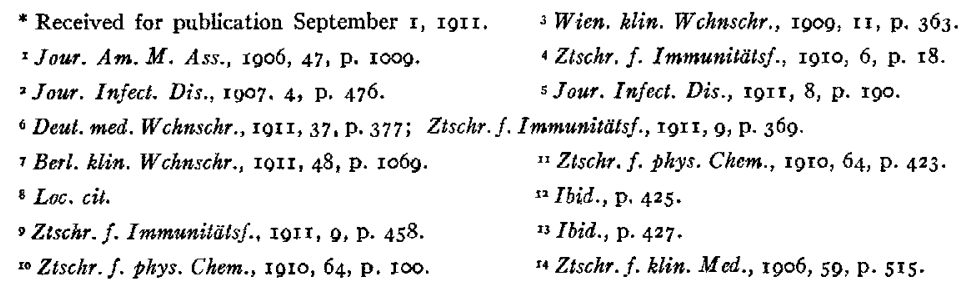


Obermayer and Pick, ${ }^{,}$the grouping upon which protein specificity depends is destroyed by the digestion of the protein. Gelatin, according to the work of Wells, ${ }^{2}$ might also be expected to give rise to substances acting upon heterologous proteins, possibly on account of the relative freedom from aromatic radicals.

It seemed desirable therefore to study the specificity of ferments developing after the injection of complex proteins. Accordingly a rabbit was injected subcutaneously at four- to six-day intervals with $2,4,6$, and Io c.c. of sheep serum. In order to avoid the complicating action of precipitins the serum was tested five weeks after the last injection, as at that time it was found that the precipitins had disappeared. The optical method of Abderhalden was used: $:^{3} 2$ c.c. of the rabbit serum were mixed with 3 c.c. of sheep serum which was heated to $56^{\circ} \mathrm{C}$. for one-half hour. The mixture was diluted $\mathrm{I}-6$ with salt solution and its optical activity immediately determined by means of the polariscope, a $10 \mathrm{~cm}$. tube being used. The remainder of the mixture was then incubated for 24 hours at $37^{\circ} \mathrm{C}$. and its optical activity again determined. All possible precaution was used to prevent bacterial contamination. A similar experiment was carried on at the same time, using the same rabbit serum but substituting bovine serum for the sheep serum. The polariscope readings follow:

\begin{tabular}{|c|c|c|}
\hline & Sheep Serum & Beef Serum \\
\hline 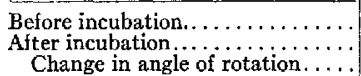 & $\begin{array}{l}0.67^{\circ} \\
0.44^{\circ} \\
0.23^{\circ}\end{array}$ & $\begin{array}{l}0.71^{\circ} \\
0.69^{\circ} \\
0.02^{\circ}\end{array}$ \\
\hline
\end{tabular}

It will be seen that a change of $0.23^{\circ}$ was found to follow the action of the rabbit serum on the sheep serum while a change of only $0.02^{\circ}$ followed the action of the rabbit serum on beef serum.

In order to test further the specificity of the proteolytic ferments of the blood, another rabbit was immunized by repeated increasing doses of suspensions of typhoid bacilli, until four agar slants were given. After five weeks the serum was tested as follows: An extract of typhoid bacilli was made by growing large quantities of typhoid bacilli on agar in Roux flasks and washing them off in

× Wien. klin. Wchtschr., Ig06, 14, p. 397. 3 Loc, cit.

Iour. Infect. Dis., r9o8, 5, p. 449 . 
distilled water. The bacilli were then dried in a vacuum desiccator at $55^{\circ} \mathrm{C}$., ground with sterile sand, and extracted with salt solution. The extract was filtered through a porcelain filter and heated to $60^{\circ} \mathrm{C}$. for one hour. In a similar way an extract of colon bacillus was made and diluted to a strength giving nearly the same degree of optical rotation as the solution of protein from typhoid bacilli. To 16 c.c. of typhoid extract 4 c.c. of sheep serum was added, and the reading taken at once with the polariscope. The mixture was incubated for $\mathbf{2 4}$ hours and a second reading made with the remaining ro c.c. Mixtures of colon-bacillus extract and rabbit serum were made in the same way, using the same rabbit serum that was used with the typhoid extract. The reading follows:

\begin{tabular}{|c|c|c|}
\hline & Typhoid Extract & Colon B. Extract \\
\hline $\begin{array}{l}\text { Before incubation................. } \\
\text { After incubation } \\
\text { Difference in angle of rotation. }\end{array}$ & $\begin{array}{l}1.05^{\circ} \\
0.70^{\circ} \\
0.35^{\circ}\end{array}$ & $\begin{array}{l}1.10^{\circ} \\
0.99^{\circ} \\
0.02^{\circ}\end{array}$ \\
\hline
\end{tabular}

It will be seen that there was a change of $0.35^{\circ}$ in the typhoid extract, whereas in the colon-bacillus-extract mixture a change of $0.02^{\circ}$ occurred. It is evident that in both the case of the serum and bacterial extracts the action of the ferments was much more marked in the case of the homologous protein than in that of the heterologous.

The action of normal rabbit serum and that of the serum of the rabbit immunized to sheep serum were compared. Two mixtures were made, using in one 2 c.c. of normal rabbit serum and 3 c.c. of sheep serum heated to $60^{\circ} \mathrm{C}$. for one-half hour, and in the other 2 c.c. of immune serum and 3 c.c. of heated sheep serum. The readings of the mixtures before and after incubation (dilution of mixture $1-6$ ) follow:

\begin{tabular}{|c|c|c|}
\hline & Immune Serum & Normal Serum \\
\hline $\begin{array}{l}\text { Before incubation................... } \\
\text { After } 24 \text {-hour incubation .......... } \\
\text { Change in angle of rotation..... }\end{array}$ & $\begin{array}{l}0.72^{\circ} \\
0.44^{\circ} \\
0.28^{\circ}\end{array}$ & $\begin{array}{l}0.70^{\circ} \\
0.56^{\circ} \\
0.14^{\circ}\end{array}$ \\
\hline
\end{tabular}


A similar experiment was made substituting, instead of normal serum, immune serum which had been heated to $56^{\circ} \mathrm{C}$. for one-half hour. The results are as follows (dilution $\mathrm{I}^{-} 5$ ):

\begin{tabular}{c|c|c}
\hline & $=\ldots$ \\
& Active Serum & Heated Serum \\
\hline Before incubation $\ldots \ldots \ldots \ldots \ldots \ldots$ & $0.86^{\circ}$ & $0.96^{\circ}$ \\
After 24-hour incubation.......... & $0.32^{\circ}$ & $0.87^{\circ}$ \\
Change in angle of rotation.... & $0.54^{\circ}$ & $0.09^{\circ}$ \\
\hline
\end{tabular}

It will be seen that there was a considerable change in the angle of rotation in the case of the normal serum $\left(0.14^{\circ}\right)$, twice as much with the immune serum, and very little $\left(0.09^{\circ}\right)$ with the heated serum. The serum used for the comparison of the active and heated serum was rich in precipitin, and it is probable that $0.09^{\circ}$ difference in rotation both in the heated and unheated serum is due to simple precipitation of optically active protein.

In order to find out whether the heated inactivated serum could be reactivated or not as in the case of the lysins, Gruber immunized animals to serum proteins and tested their action on silk peptone, using the optical method. He failed to obtain any reactivation. We must assume that any specific ferments comparable to amboceptors are concerned only in the splitting of the protein molecule to a point where the specific grouping is destroyed. In order to further digest these split products an excess of non-specific proteinsplitting substances might be assumed. These ferments would be comparable to complement which is non-specific and cannot be reactivated. It is possible, therefore, that Gruber, in using silk peptone as an indicator, was attempting to reactivate only the non-specific ferments of Abderhalden.

The following attempt was made to reactivate a specifically proteolytic serum. Three mixtures were made:

Mixture I: Heated immune serum I c.c., complement (guineapig serum) I c.c., sheep serum 3 c.c.

Mixture 2: Heated immune serum I c.c., salt solution I c.c., sheep serum 3 c.c.

I Ztschr. f. Immunitätsf., 1910, 7 , p. 762 . 
Mixture 3: Salt solution I c.c., complement I c.c., sheep serum I c.c.

The following are the readings of dilutions $\mathbf{I}-6$ of the mixtures, before and after 24-hour incubation:

\begin{tabular}{|c|c|c|c|}
\hline & Mixture $I$ & Mixture 2 & Mixture 3 \\
\hline $\begin{array}{l}\text { Before incubation. } \ldots \ldots \ldots \ldots \ldots \ldots \ldots \ldots \\
\text { After incubation. } \ldots \ldots \ldots \ldots \ldots \ldots \ldots \\
\text { Change in angle of rotation. } \ldots \ldots \ldots \ldots\end{array}$ & $\begin{array}{l}0.62^{\circ} \\
0.34^{\circ} \\
0.28^{\circ}\end{array}$ & $\begin{array}{l}0.60^{\circ} \\
0.58^{\circ} \\
0.02^{\circ}\end{array}$ & $\begin{array}{l}0.53^{\circ} \\
0.39^{\circ} \\
0.14^{\circ}\end{array}$ \\
\hline
\end{tabular}

The difference of $0.14^{\circ}$ between Mixtures I and 3 can hardly be due to an additive effect, because the heated serum alone was almost without influence. It would appear to be rather in the nature of a reactivation.

\section{CONCLUSIONS.}

The results of these experiments would indicate that the proteolytic substances of the blood are of a nature resembling that of the immune bodies, especially the lysins. 